\title{
POLLUTANT EMISSIONS FROM MODERN INCINERATORS
}

Rui Lima (IPB, ESTiG, Bragança Polytechnic Institute, Portugal)

Email: ruimec@ipb.pt

Robert Th. Bachmann (Sheffield University, Chem Proc Eng. Dept., Sheffield S1 3JD, U.K.)

Email: r.t.bachmann@sheffield.ac.uk

\begin{abstract}
Presently, emissions of dioxins are mainly from incinerators, domestic and industrial coal combustion, and traffic. However, the major public concern and research effort are associated with the emissions of organic micropollutants from waste incinerators. Therefore, this paper attempts to give a brief overview on the more recent research and development for the removal of dioxins and heavy metals from flue gas streams. Special attention is devoted to the origin and control of emissions from incinerators.

From the study presented it is possible to conclude that flue gas cleaning systems in modern incinerators are very reliable in removing almost all polluting emissions from flue gas streams, however the fly ash residues generated pose a significant disposal problem. In this way, the fly ash has to be managed carefully as it is enriched with heavy metals and organic micropollutants.
\end{abstract}

KEY WORDS : incineration, fly ash residues, dioxins, heavy metals, polluting emissions, organic micropollutants

\section{INCINERATION}

The incineration process consists of a number of stages: drying (mainly at $50-200{ }^{\circ} \mathrm{C}$ ), degasification (mainly at $250-400{ }^{\circ} \mathrm{C}$ ), gasification (mainly at $400-600^{\circ} \mathrm{C}$ ) and combustion (mainly at $\left.>600{ }^{\circ} \mathrm{C}\right)$ [23].

In the past, about 30 municipal solid waste incinerators were operated in the UK, some of which had no flue gas cleaning system. However, over the last fifteen years, advancements in incinerator research and development as well as more stringent emission limits have resulted in equipping the majority of municipal waste incinerators with flue gas cleaning systems and energy recovery boilers. Energy recovery, via district heating and electricity generation as illustrated in Figure 1, is an exemplary way of ensuring economic as well as ecological viability of the incineration process.

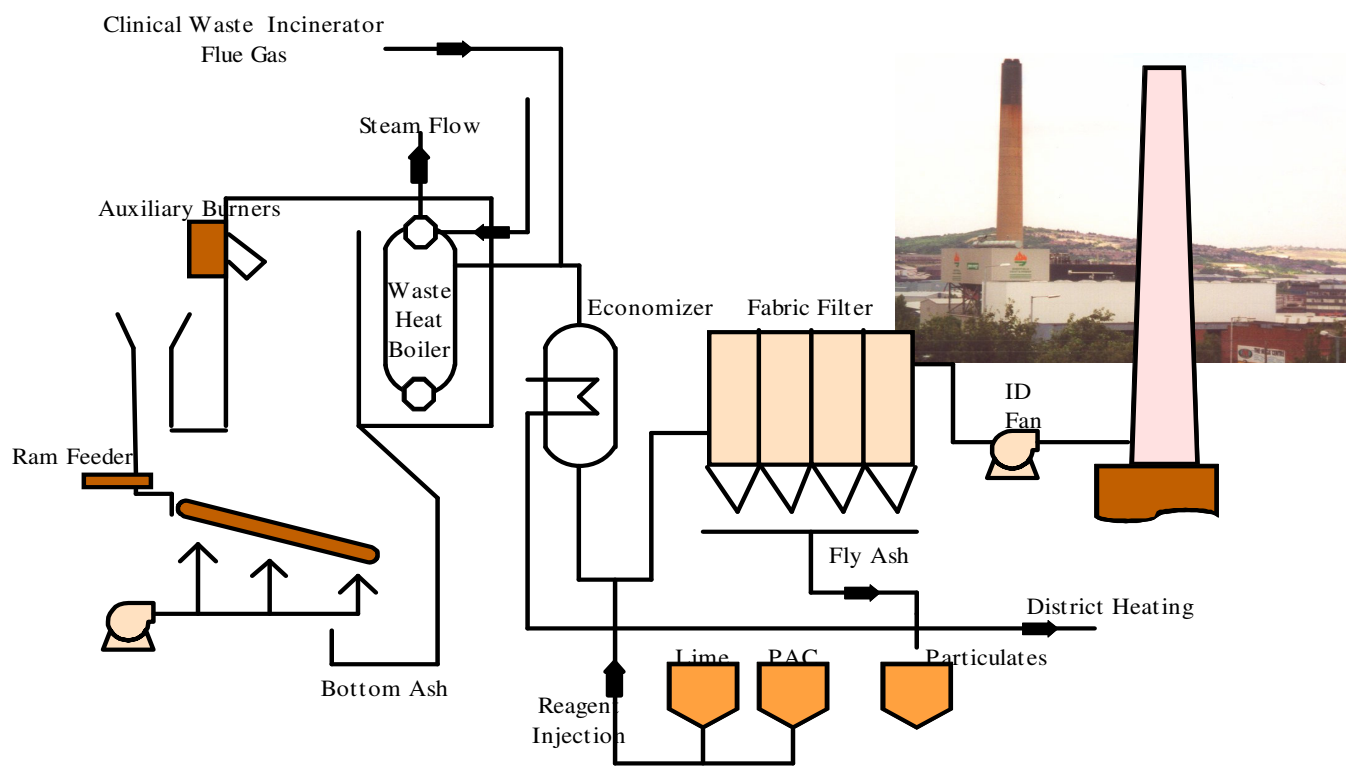


Figure 1 - Schematic of typical modern municipal waste incinerator plant.

Over the years, the incineration of municipal solid waste (MSW) in 'waste-to-energy' facilities has become a widespread and growing practice in some western European countries such as Germany, the United Kingdom, Denmark, Sweden and Switzerland, but also in Japan [23]. The Sheffield incinerator in the UK is a very good example of how energy recovery has successfully been employed. David Lawrence, Chief Executive of Sheffield Heat and Power (SHP - responsible for the operation of the Sheffield incinerator) pointed out that "the beauty of Sheffield Heat and Power lies in the simplicity of the product it supplies - energy from waste" [10].

\section{POLLUTANT EMISSIONS TO THE ATMOSPHERE}

There is a great variety of emissions originating from incinerators, such as heavy metals, carbon monoxide, dioxines, polycyclic aromatic hydrocarbons (PAHs), etc.[11]. Table 1 summarises the most important pollutants associated with the incineration of waste. Waste incineration is reported to be one of the important sources of dioxin and hydrochloric acid emissions into the air [28]. In addition, Nriagu and Pacyna [27] also indicated that waste incineration contributes strongly to the total emissions of heavy metals.

Table 1 - Pollutants associated with waste incineration.[11]

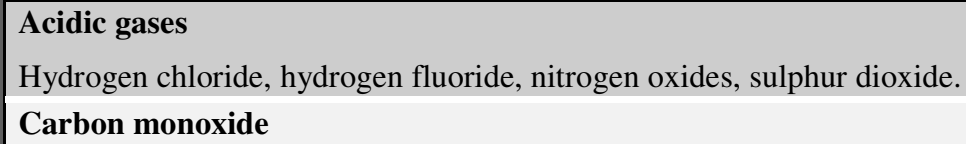

Heavy metals can appear in different chemical forms, including soluble salts such as chlorides and sulphates and less soluble oxides and silicates. Most of the mercury present is released as a vapour, as is some cadmium.

\section{Organic material}

Organic material occurs in volatile forms, as well as bound to particulates. A large number of organic compounds can be present if combustion has not been complete or if compounds are allowed to form after incineration has taken place. An important class of such compounds is dioxins.

\section{Particulates}

Fine particles of inorganic materials such as silica have metals and organic material adhering to them. The size distribution and thus surface area, of such particles can vary widely, as can their chemical composition and their ability to bind other materials.

\section{Carbon dioxide $\left(\mathrm{CO}_{2}\right)$}

If adequately dispersed, is not conventionally regarded as a pollutant relevant to health or the local environment, and is thus not subject to direct regulatory control. It is however a contributor to the greenhouse effect.

However, emission of dioxins, furans and heavy metals can be reduced by efficient abatement technologies [13] some of which are listed in Table 2.

The concentration of some pollutants is directly related to the composition of waste that is feed into the combustion chamber. For example, the oxides of nitrogen $\left(\mathrm{NO}_{\mathrm{x}}\right)$ can be formed either by the oxygenation of nitrogen in the waste or by fixation of atmospheric nitrogen in a high temperature flame.[11]. 
Table 2 - Air pollution control methods and efficiencies.[13]

\begin{tabular}{|c|c|c|}
\hline Pollutant & Control Methods & Typical Reduction (\%) \\
\hline$\overline{\mathrm{NO}_{\mathrm{x}}}$ & $\begin{array}{l}\text { Selective catalytic reduction, } \\
\text { selection non-catalytic reduction, } \\
\text { flue gas recirculation, combustion } \\
\text { control }\end{array}$ & 10 to 60 \\
\hline $\begin{array}{l}\text { Acid Gases } \\
\left(\mathrm{SO}_{\mathrm{x}} \text { and } \mathrm{HCl}\right)\end{array}$ & $\begin{array}{l}\text { Wet scrubber, dry scrubber, fabric } \\
\text { filter, electrostatic precipitator }\end{array}$ & $\begin{array}{l}50 \text { to } 85 \mathrm{SO}_{\mathrm{x}} \\
75 \text { to } 90 \mathrm{HCl}\end{array}$ \\
\hline $\mathrm{CO}$ & Combustion control & 50 to 90 \\
\hline Heavy Metals & $\begin{array}{l}\text { Dry scrubber, fabric filter, } \\
\text { electrostatic precipitator }\end{array}$ & 70 to 95 \\
\hline Particulates & $\begin{array}{l}\text { Electrostatic precipitator, fabric } \\
\text { filter }\end{array}$ & 95 t0 99.99 \\
\hline $\begin{array}{l}\text { Toxic Organics } \\
\text { (PCDD, PCDF, } \\
\text { etc.) }\end{array}$ & $\begin{array}{l}\text { Combustion control, combination } \\
\text { of dry scrubber and fabric filter }\end{array}$ & 50 to 99.99 \\
\hline
\end{tabular}

The composition of MSW in turn is a function of the industrialisation level of the city or the country, geographic location, season, and the recycling capability of a country [24]. For example, more than half of the fraction of MSW in Portugal is food and garden waste while in Finland, more than half of the MSW is paper waste. Table 3 summarises the typical composition of MSW expressed in weight per cent for selected countries.

Table 3 - Composition of MSW expressed in weight per cent for selected countries.

\begin{tabular}{|c|c|c|c|c|c|c|c|c|c|}
\hline Country & 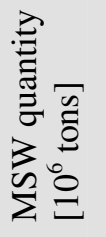 & 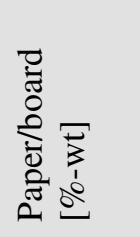 & 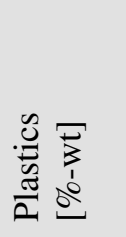 & 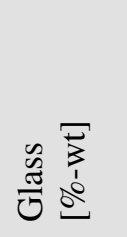 & 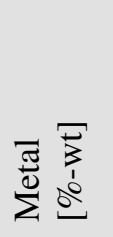 & 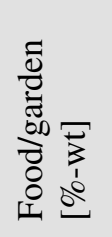 & 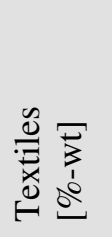 & 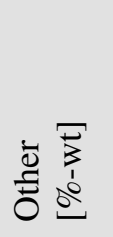 & 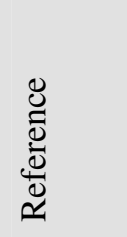 \\
\hline Belgium & & 30.0 & 4.0 & 8.0 & 4.0 & 45.0 & & 9.0 & [24] \\
\hline Finland & & 51.0 & 5.0 & 6.0 & 2.0 & 29.0 & 4.0 & 12.0 & [21] \\
\hline France & & 31.0 & 10.0 & 12.0 & 6.0 & 25.0 & 4.0 & 12.0 & [24] \\
\hline Germany & 43.5 & 19.9 & 6.1 & 11.5 & 3.9 & 27.0 & 1.5 & 30.1 & [22] \\
\hline Japan & 50.2 & 25.0 & 11.2 & 2.9 & 5.1 & 42.3 & 5.5 & 8.0 & {$[22]$} \\
\hline Portugal & & 23.0 & 4.0 & 3.0 & 4.0 & 60.0 & & 6.0 & {$[24]$} \\
\hline UK & 29 & 34.8 & 11.3 & 9.1 & 7.3 & 19.8 & 2.2 & 15.5 & {$[25,26]$} \\
\hline USA & 207 & 37.6 & 9.3 & 6.6 & 8.3 & 22.6 & 15.6 & 8.5 & [22] \\
\hline
\end{tabular}

There are several emission limits for municipal solid waste incinerators. However, the emissions that receiving the greatest interest and concern by the regulating authorities, research and the public are mainly dioxins and heavy metals. Consequently, this paper is primarily devoted to the discussion of the origin and control of dioxins and heavy metals from modern incinerators. 


\subsection{HEAVY METALS}

The MSW contains metals such as $\mathrm{Pb}$ from lead-based paints, zinc ( $\mathrm{Zn}$ ) sheets, $\mathrm{Cd}$ and $\mathrm{Hg}$ mainly from batteries, aluminium $(\mathrm{Al})$ foils, etc. However, in the incineration of waste special attention must be devoted to metals such as $\mathrm{Cd}, \mathrm{Cr}, \mathrm{Pb}$ and $\mathrm{Hg}$, mainly because of their explicit toxicity.[9, 23]. $\mathrm{Cu}$, Platinum (Pt) and $\mathrm{Ni}$ tend to be less toxic but they are potent catalysts and contribute to a complex organic chemistry in the flue gases of combustion plants (eg. postformation of dioxins in flue gases) [23].

In general, heavy metals evaporate in the combustion chamber due to complex and interrelated factors (operating temperature, oxidative or reductive conditions, etc). After that, they condense in colder parts of the flues and generate an aerosol of submicron particles or they may become adsorbed onto fly ash particles.[1]

As shown in table 2, there is a wide range of methods available for the removal of heavy metals from the flue gas stream. However, in order to comply with the current legislation, the most common method being used is the combination of the dry lime injection process and fabric filters. Alternatively, the injection of activated carbon instead of dry lime allows the removal of dioxins from the flue gas stream. [9]

Ideally however, it would be desirable to minimise heavy metals in untreated MSW in the first place. For example, the recycling of batteries can add to the reduction of the heavy metal load of MSW and subsequently the emission load of Cd and $\mathrm{Hg}$. [9]

\subsection{DIOXINS AND FURANS}

At present, organic micro-pollutants such as dioxins and furans are one of the most urgent public concerns, related to pollutant emissions to the atmosphere.

Dioxins and furans - polychlorinated dibenzo-p-dioxins (PCDD), known as "dioxin", and polychlorinated dibenzo furans (PCDF), known as "furan", form the family of chlorinated organic compounds.[1] There are many different compounds in the $\mathrm{PCDD} / \mathrm{F}$ family, each determined by the number and arrangement of chlorine atoms occupying the outer ring positions of the molecule (see table 3). Overall, there are about 210 dioxins and furans, 17 of which are very toxic. For example, the 2,3,7,8-tetra-chlorinated dibenzo-p-dioxins, for example, is the most toxic dioxin.[3, 18]

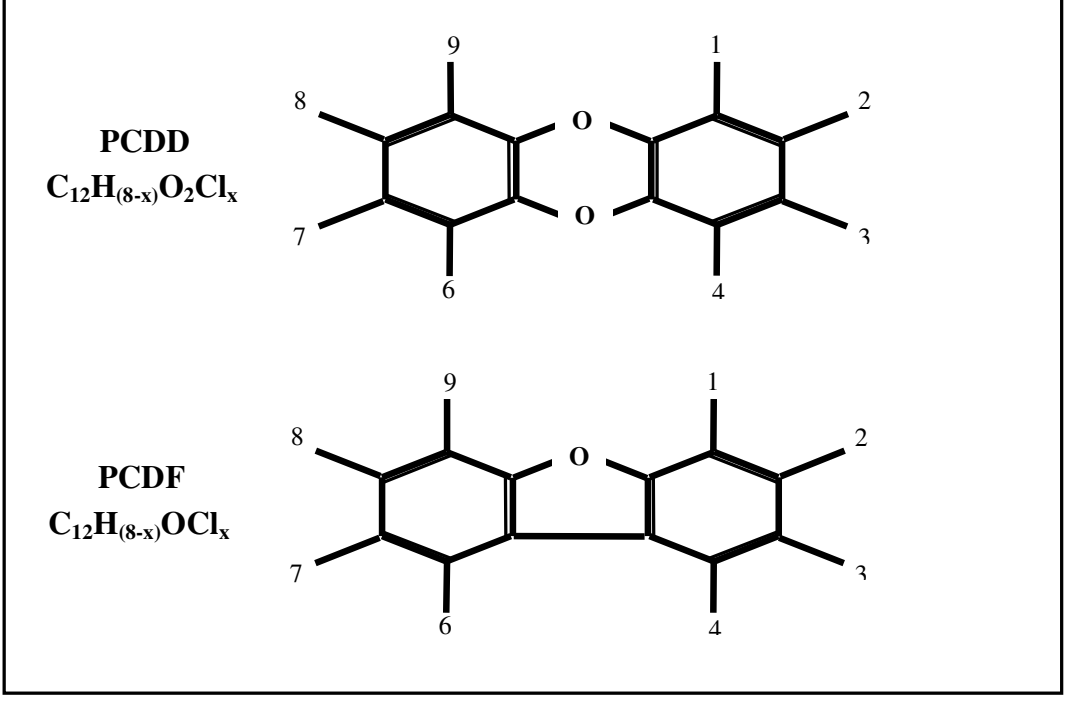

Figure 2 - Dioxin and furan molecules and the 2,3,7,8-tetra isomers, from [18]. 
Table 4 - The homologue and congeners of PCDD/Fs. [18]

\begin{tabular}{||c|c|c|c||}
\hline \multirow{2}{*}{ Homologue (abbreviation) } & \multirow{2}{*}{$\begin{array}{l}\text { Number of } \\
\text { Chlorine atoms }\end{array}$} & \multicolumn{2}{|c||}{ Number of Congeners } \\
\cline { 3 - 4 } & & 2 & PCDDs \\
\hline \hline Monochloro (M) & 1 & 10 & 4 \\
\hline Dichloro (D) & 2 & 14 & 16 \\
\hline Trichloro (Tr) & 3 & 22 & 28 \\
\hline Tetrachloro (T) & 4 & 14 & 28 \\
\hline Pentachloro (Pe) & 5 & 10 & 16 \\
\hline Hexachloro (Hx) & 6 & 2 & 4 \\
\hline Heptachloro (Hp) & 7 & 1 & 135 \\
\hline Octachloro (O) & 8 & 75 & 1 \\
\hline \hline
\end{tabular}

The toxicity of the 2,3,7,8-substitute congeners is generally considered to decrease with increased chlorination of the compound. For instance, 1,2,3,4,7,8-HxCDD (6 chlorine atoms) is considered less toxic than 1,2,3,7,8-PeCDD (5 chlorine atoms). Therefore, the toxicity of the congeners of PCDD/Fs are defined as a International Toxic Equivalent Factors (I-TEF) expressed as fraction of 2,3,7,8-TCDD taken as unity. On this scale other dangerous individual compounds are 1,2,3,7,8-PeCDD $(\mathrm{I}-\mathrm{TEF}=0.5)$ and $2,3,4,7,8-\mathrm{PeCDF}(\mathrm{I}-\mathrm{TEF}=0.5) .[18,41]$

Table 5 - 2,3,7,8-substituted congener PCDD/Fs with International Toxic Equivalent Factors (ITEF). [18]

\begin{tabular}{|c|c|c|c|}
\hline PCDDs & I-TEF & PCDFs & I-TEF \\
\hline 2,3,7,8-TCDD & 1 & $2,3,7,8-\mathrm{TCDF}$ & 0.1 \\
\hline 1,2,3,7,8-PeCDD & 0.5 & $\begin{array}{l}1,2,3,7,8-\mathrm{PeCDF} \\
2,3,4,7,8-\mathrm{PeCDF}\end{array}$ & $\begin{array}{c}0.05 \\
0.5 \\
\end{array}$ \\
\hline $1,2,3,4,7,8-\mathrm{HxCDD}$ & 0.1 & $1,2,3,4,7,8-\mathrm{HxCDF}$ & 0.1 \\
\hline 1,2,3,6,7,8-HxCDD & 0.1 & $\begin{array}{l}1,2,3,6,7,8-\mathrm{HxCDF} \\
2,3,4,6,7,8-\mathrm{HxCDF}\end{array}$ & $\begin{array}{l}0.1 \\
0.1 \\
\end{array}$ \\
\hline $1,2,3,7,8,9-\mathrm{HxCDD}$ & 0.1 & $1,2,3,7,8,9-\mathrm{HxCDF}$ & 0.1 \\
\hline 1,2,3,4,6,7,8-HpCDD & 0.01 & $\begin{array}{l}1,2,3,4,6,7,8-\mathrm{HpCDF} \\
1,2,3,4,7,8,9-\mathrm{HpCDF} \\
\end{array}$ & $\begin{array}{l}0.01 \\
0.01 \\
\end{array}$ \\
\hline OCDD & 0.001 & OCDF & 0.001 \\
\hline
\end{tabular}

Concern about dioxins is primarily due to their carcinogeneity and toxicity. In fact, they can persist in the environment for several years, and have a tendency to bioaccumulate in animal tissue and consequently they may pass on into the human food chain. [18] 


\subsubsection{ORIGIN OF DIOXINS}

It is commonly reported that the Dioxins are formed due to the products of incomplete combustion. On the other hand, there are a wide number of theories proposing a combination of conditions, responsible for the formation of dioxins during combustion.[1]

Research, conducted by some researchers, has suggested the following reactions for the formation of dioxins:

During combustion: formation of dioxins, which, owing to their presence in the waste and because of their thermal stabilities, survive the combustion process particularly at lower temperatures.[12]

During incineration: dioxins are produced via reactions between precursors such as polychlorinated biphenyls (PCB), chlorinated benzenes, etc. These precursors can be seen in the waste or formed via combustion of plastics. However, a number of researchers, namely Buekens, Scoeter and Visalli [9], demonstrated that there is no relationship between PVC plastic or hydrogen chloride $(\mathrm{HCl})$ and dioxins emissions from the incinerator.[1]

Post-combustion ("de novo synthesis"): it has been claimed, by a large numbers of researchers, that the dominant mechanism of dioxin formation involves reactions between clorinated precursors and/or the products of "de novo synthesis". These reactions take place especially on the fly ash particles at relatively low temperatures $\left(200^{\circ} \mathrm{C}-400^{\circ} \mathrm{C}\right)$, which can be found in the post-combustion environment of the boiler or at arrestment equipment. Metal compounds present on the fly ash surfaces, mainly copper and iron, are thought to act as catalysts as mentioned previously. Moreover, precursors such as PAH and other organics adsorb onto the surface of ash particles, and at active places where metal compounds are present, PCDD/Fs formation occurs by catalysis. [12, 18]

\subsubsection{TECHNIQUES FOR CONTROLLING DIOXINS AND EMISSIONS TO ATMOSPHERE}

A general understanding of the mechanism of formation of dioxins emissions is fundamental for the design of control systems. Owing to the controversy about the origin of dioxins as discussed in the previous section, there are generally two main ways of controlling these emissions:

\section{i) Combustion Control}

An efficient combustion control is correlated with a destruction of dioxins greater than 99.99\%.[12] The combustion control targets on parameters such as temperature, combustion air and turbulence. The current legislation in the UK is focused on combustion efficiency with minimum furnace temperatures of $850^{\circ} \mathrm{C}$, for at least 2 seconds in the presence of at least $6 \%$ of $\mathrm{O}_{2} \cdot[9]$

It is generally agreed that thermal destruction increases exponentially with temperature, and that combustion temperatures of $1000^{\circ} \mathrm{C}$, with a residence time of $1 \mathrm{~s}$, are adequate for total destruction.[1, 12]

Generally, the modern incinerators are equipped by a primary combustion chamber followed by a secondary combustion chamber, in order to ensure a more complete destruction of the waste components. As a result, less unburned organic and products of incomplete combustion (PICs) are formed, and therefore, a reduced potential for heterogeneous reactions involving precursors of PCDDs, PCDFs, and PAHs.[12]

\section{ii) Post-Combustion Control}

A large number of researchers including Hagemnair and Haag[9] have claimed that the "de novo synthesis" is the dominant formation mechanism for dioxins. Therefore, several techniques have been developed removing dioxins from flue gas streams: 
- Fabric filters (increasingly used due to their greater particles removal efficiency).[12]

- Dry/wet scrubbers with lime as the active scrubbing agent, (seems to be another good efficient way of removing dioxins. However wet systems are not that effective since some dioxins have a very low solubility in water.)[1]

- Combination of dry scrubber and fabric filter (typical dioxin emission reduction of 5099.9\%) [13]

a Combination of activated carbon injection and fabric filters (guarantees emissions of $0.1\left(\mathrm{ng} / \mathrm{Nm}^{3}\right)$ for dioxins. $)[14]$

a Combination of electrostatic precipitator, wet scrubber and fabric filter (filsorption stage filtration, sorption and chemical reaction in fabric filter). The results of this combination are extremely good, as is shown in table 6. [17]

Table 6 - Results of emission measurements at the incinerator plant in Zirndorf, Germany. Concentrations in $\mathrm{ng} / \mathrm{m}^{3}$ dry gas $11 \% \mathrm{O}_{2} \cdot[17]$

\begin{tabular}{|c|c|c|c|}
\hline Parameter & Measurements(Dec1991) & Measurements(May1992) & German Regulation \\
\hline I-TEQ-Dioxin & $<0.01$ & $<0.01$ & 0.1 \\
\hline
\end{tabular}

Although almost all dioxins and heavy metal emissions are removed from flue gas streams, the flyash residues generated pose a significant disposal problem.

\section{CONTAMINATED ASH}

State-of-the-Art technology in concert with a good design offers the key to meet very high standards of pollution control. However, secondary waste products from the municipal waste combustion (MWC) process such as solid residues or waste-water from quenching and gas scrubbing processes must be managed in an environmentally acceptable way.

The solid residues from the incineration process are one of the major concerns due to the presence of heavy metals and organic micropollutants in these ashes. The ash residues are normally classified as (see Figure 3):

Bottom ash - ash from the furnace grate which represents $85-90 \%$ of the total ash. The concentration of heavy metals and dioxins are generally quite low. Therefore, this ash is usually disposed directly to landfill.

Fly ash - particulate matter carried over from the combustion chamber, incorporating metals and organic material, including dioxins, volatiles condensed during flue gas cooling and other products of incomplete combustion. This ash represents $10-15 \%$ of the total ash and sometimes is mentioned as the air pollution control (APC) residues. Fly ash is usually recovered using both electrostatic precipitators and bag-house filters.

Combined ash - is a mixture of all residue streams. [15, 11]

The disposal of both bottom and fly ash, produced by the combustion process, has to be managed in an economical and environmental-friendly way. However, special attention must be devoted to the fly ash as it is enriched in heavy metals and organic micropollutants (dioxins, PAHs, etc). For example, fly ash is considered as a hazardous material by legislation in many countries due to its heavy metal content, $\mathrm{PCDD} / \mathrm{Fs}$ and other potentially harmful organic compounds such as PAHs. [16] 


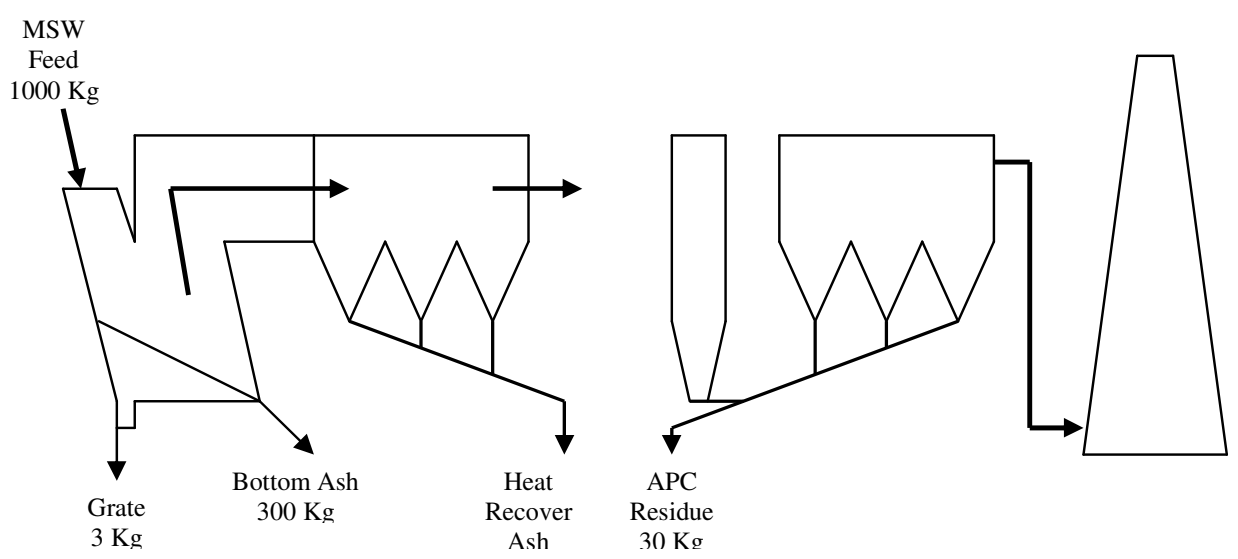

Figure 3- Sources of ash residues in the MSWI from [15].

Another important aspect is that various pollutants present in the fly ash become increasingly hazardous when placed in landfill where leaching of the pollutants can be a source of groundwater contamination. [9]

\section{Conclusion}

Pollution control technology for municipal incinerators has developed considerably for the last ten to fifteen years. Several reliable systems, such as fabric filters (with a pre-addition of activated carbon) and scrubbers, to remove dioxins and heavy metal emissions almost completely, are commercially available. The combination of those systems with an efficient combustion control is the key to obtain almost zero micropollutants emissions to the atmosphere. However, the fly ash residues generated by such systems pose a significant disposal problem.

Overall, the technology available together with a good design and efficient management maybe will gain full public acceptance in a near future. However, an element of uncertainty is always inevitable, related essentially to an incomplete knowledge of the formation of dioxins present in the organic emissions. This has added to continuing demands for further research on this issue.

\section{References}

[1] Williams, Paul T., "Waste Treatment and Disposal”, West Sussex: John Wiley and Sons Ltd, 1998.

[2] Sharifi, V. N., "Lecture notes: Incineration", Sheffield University, Department of Chemical and Process Engineering, 1999.

[3] Porteous, Andrew, "Dictionary of Environmental Science and Technology", $2^{\text {nd }}$ ed. West Sussex: John Wiley and Sons Ltd, 1996.

[4] Bahu, R., Crittenden, B., O`Hara, J., "Management of Process Industry Waste", Institution of Chemical Engineers, UK,1997.

[5] Kiely, G., "Environmental Engineering", McGraw-Hill, UK, 1997.

[6] Council Directive 89/369/EEC, On the prevention of air pollution from new municipal incinerator plants, OJ No. L163/2, 14/06/89.

[7] Council Directive 89/429/EEC, On the reduction of air pollution from existing municipal incinerator plants, OJ No. L203/50, 15/07/89. 
[8] Council Directive 94/67/EEC, on the incineration of hazardous waste, 16 December 1994.

[9] Williams, Paul T.; "Pollutants from Incineration: An Overview" Issues in Environmental Science and Technology - Waste Incineration and the Environment, The Royal Society of Chemistry, 1994.

[10] Sheffield Heat and Power ; "Providing the Energy of the Future Today"; Sheffield, 1998.

[11] Royal Commission on Environmental Pollution, "Seventeenth Report Incineration of Waste", HMSO, London, 1993.

[12] Eduljee, G.; "Organic Micropollutant Emissions from Waste Incineration" Issues in Environmental Science and Technology - Waste Incineration and the Environment, The Royal Society of Chemistry, 1994.

[13] Savage, G. et al. "Important Issues Related to Air Pollution at Municipal Solid Waste Facilities" Environmental Progress, Vol.17, N², May 1988.

[14] Rae, G.; "Recovering Energy from Waste: Emissions and Their Control" Issues in Environmental Science and Technology - Waste Incineration and the Environment, The Royal Society of Chemistry, 1994.

[15] Lee, Poh Hoon; "Development of a Novel Technology for the Detoxification of Fly Ash Produced by Waste Incineration Industry", PhD Thesis, Sheffield University, Department of Chemical and Process Engineering, Sheffield, April, 1999.

[16] Guyer, H.; "Industrial Processes and Waste Stream Management." John Wiley and Sons Ltd, West Sussex, 1998.

[17] Sharifi, V. N., "Flue Gas Emissions Control", Lecture notes: Incineration., Sheffield University, Department of Chemical and Process Engineering, Sheffield, 1999.

[18] Ward, D., "An Investigation Into The Detoxification Of Dioxin Contained Fly Ash By Energy Efficient Sintering." MSc(Res) Materials, Structures and Systems Engineering, Sheffield University, Department of Chemical and Process Engineering, Sheffield, 1999.

[19] Alloway B. and Ayres D.; "Chemical Principles of Environmental Pollution", Blackie Academic and Professional, 1997.

[20] Niessen, W.; "Combustion and Incineration Processes", Marcel Dekker, Inc; New York, 1978.

[21] Ettala, M.O., "Sanitary Landfilling in Finland"; International perspectives on municipal solid wastes and sanitary landfilling. a report from the International Solid Wastes and Public Cleansing Association (ISWA) Working Group on Sanitary Landfilling (WGSL). edited by Joseph S. Carra,Raffaello Cossu, London. Academic Press, pp. 67-77, 1990.

[22] Sakai, S., S. E. Sawell, A. J. Chandler, T. T. Eighmy, D. S. Kosson, J. Vehlow, H. A. van der Sloot, J. Hartlén and O. Hjelmar, "World Trends in Municipal Solid Waste Management"; Waste Management, Vol. 16(5-6), pp. 341-350, 1996.

[23] Schmid, J., Elser, A., Ströbel, R. and Crowe, M., "Dangerous substances in waste"; Technical Report No 38, European Environment Agency, 2000.

[24] OECD, "Environmental Data Compendium", Organisation for Economic Cooperation and Development, Paris, 1999.

[25] Department of the Environment, "Externalities from landfill and incineration. A study by CSERGE, Warren Spring Laboratory and EFTEL [i.e. EFTEC]"; HMSO, London, ISBN: $0117528250,1993$.

[26] Mitchell, D.J., S.R. Wild and K.C. Jones, "Arrested municipal solid waste incinerator fly ash as a source of heavy metals to the UK environment"; Environmental Pollution, Vol. 76(1), pp. 79-84, 1992.

[27] Nriagu, J.O. and J.M. Pacyna, "Quantitative assessment of worldwide contamination of air, water and soils with trace metals"; Nature, Vol. 333: pp. 134-139, 1988. 